\title{
Theoretical and Legal Understanding of the Category "Political System" in the Context of Development in Central Asian Governments
}

\author{
Nazira Kolsarieva', Erkin Duisenov², Ravil Mazitov³, Niiazbek Pazylov³, Zhypargul Abdullaeva ${ }^{4}$ \\ ${ }^{1}$ Department of Theory and History of Government Law, Osh State Juridical Institute, Osh, Kyrgyzstan \\ ${ }^{2}$ Constitutional, International Law and Customs Department, Eurasian Law Academy named after D.A. Konaev, Almaty, \\ Kazakhstan \\ ${ }^{3}$ Department of Civil Law and Procedure, Osh State Juridical Institute, Osh, Kyrgyzstan \\ ${ }^{4}$ Science and Research Department, Osh State University, Osh, Kyrgyzstan \\ Email: *jypar.science@oshsu.kg
}

How to cite this paper: Kolsarieva, N., Duisenov, E., Mazitov, R., Pazylov, N., \& Abdullaeva, Z. (2021). Theoretical and Legal Understanding of the Category "Political System" in the Context of Development in Central Asian Governments. Open Journal of Social Sciences, 9, 128-142.

https://doi.org/10.4236/jss.2021.99009

Received: August 1, 2021

Accepted: September 3, 2021

Published: September 6, 2021

Copyright $\odot 2021$ by author(s) and Scientific Research Publishing Inc. This work is licensed under the Creative Commons Attribution International License (CC BY 4.0).

http://creativecommons.org/licenses/by/4.0/

\begin{abstract}
The article presents a comprehensive theoretical and legal analysis of the category "political system" based on constitutional legislation in Central Asian (CA) governments. It is recognized that formation of governments in Central Asia during the transition period to a new democracy took place in the context of models transit focused on a theory of political transformation and modernization, explaining the sources, goals and direction of changes from totalitarianism to democracy. In the course of analysis, a wide toolkit of methodological vectors was used based on the leading scientists well established views, both far abroad, as well as Russian and domestic authors. The importance of knowledge about political systems that goes beyond the traditional framework recognized, conditioning the comparative studies of individual elements of the basic theory of law and applied disciplines, which makes it possible to augment certain knowledge in a universal theory used in most commonwealth of independent state (CIS) countries in scientific projects. In the context of the analysis, the definition of the political system is formed as an established system of the state, in which its constituent institutions are formed as a result of the long evolution of a particular government. Some aspects in the patterns of functioning of political systems were also considered including the study of theoretical and methodological issues affecting the concept development, the formation of political and legal relations. The structure of political systems is considered in the Central Asian governments' example.
\end{abstract}




\section{Keywords}

Political System, Constitutional Development, Sovereignty, Transformation, Modernization, Democracy, Political Regime, Government form, Transition Period, Regional Studies

\section{Introduction}

The well-known events of the USSR collapse in 1991 led to formation of new governments on the territory of Central Asia, which in their Constitutions determined a political orientation for the future as the construction of democratic open societies. That is why Kyrgyz researcher B. Sydykov mentioned that "strengthening the independence of the young sovereign governments in Central Asia presupposes their close socio economic, political, cultural cooperation within the region as a whole" (Sydykov, 2014: p. 27).

Presented analysis forms and ideas about political system understanding from theoretical expanding and applied science positions will contribute to rational navigation ability of the government complex problems and the law theories.

The research analysis focused on analytical nature of definition about an understanding of political system based on the government theory, development of links in basic disciplines, such as the government and law theories in comparative jurisprudence, applied comparative political science and regional studies.

In the context of current processes intensification due to the growth of interdependence, the significance of knowledge about political systems goes beyond the framework, conditioning the comparative studies of individual elements of the basic theory of law and applied disciplines, transforming into a universal theory used in most CIS countries in the field of scientific research (Amanbaev \& Aitieva, 2009).

It is logical to call the subject of defining the political system, the complex political and legal relations between the subjects that develop in the course of socio-political processes, which were manifested in the patterns of Central Asian governments (Malysheva, 2018: p. 36) development.

The independent governments in Central Asia occupy a total of about 4 million square meters and a population of 55 million people. Kazakhstan covers an area of 2.7 million $/ \mathrm{km}^{2}$, with a population of 18 million people; Kyrgyzstan area is 199.7 thousand $/ \mathrm{km}^{2}$, with a population of 6.5 million people; Turkmenistan area is 491.2 thousand $/ \mathrm{km}^{2}$, with a population of 5.4 million people; Uzbekistan area is 447.4 thousand $/ \mathrm{km}^{2}$ with a population 25.6 million people; Tajikistan area is 143.1 thousand $/ \mathrm{km}^{2}$ with a population 6.2 million people. In the conditions of sovereignty in the analyzed CA states, group solidarity based on the principle of ethnic loyalty has become a mobilizing force. It is worth recognizing that the formation of governments in Central Asia during the transition period to a new democracy proceeded in the context of transit models (Elebaeva \& Pukhova, 2007: 
p. 91). For each government, most important condition for overcoming the crisis is the presence of optimal development strategies for the future. Of course, this presupposes the formation of conditions and prerequisites for a change of paradigms (Artykbaev et al., 2009).

In this article, the tools used in the analysis are theoretical and methodological approaches to the governments' analysis, patterns and trends in the development of their political systems and the developed measures with means of implementing political and legal decisions serving the government and citizens interests.

In the government theory, as in any social science, there are no true or false concepts and approaches. It should be recognized that the positioned ideas are discursive and subject to multidimensional comprehension. Consequently, the approaches used in the analysis are sublimate and built based on several related disciplines of socio humanitarian studies, and the main pivot is a logical presentation of established scientific positions, based on pluralism of theoretical views, which allow solving the problems of emerging political systems (Melnikov, 2018).

A political system based on constitutional legislation characterized by the government's purpose of dialogue with opposition and the triumph of democracy; nationwide discussions were initiated on preparation of changes and additions to the constitution (Shukuralieva, 2007: p. 14).

Election rules stated in the Kyrgyz Republic constitution articles dated June 27, 2010:

1) The people of Kyrgyzstan are the bearers of sovereignty and the only source of state power in the Kyrgyz Republic;

2) The people of Kyrgyzstan exercise their power directly at elections and referendums, as well as through the system of state bodies and bodies of local selfgovernment based on this Constitution and laws;

3) Laws and other important issues of national importance may be submitted to a referendum (popular vote). The procedure for holding a referendum and the list of issues submitted for a referendum are established by constitutional law;

4) Elections are free;

5) The Kyrgyz Republic (Kyrgyzstan) is an independent, sovereign, democratic, unitary, legal, secular and social government (Central Commission for Elections and Referendums, 2021).

Political frameworks in the constitutional order stated in the Kyrgyz Republic Constitution:

1) The Kyrgyz Republic (Kyrgyzstan) is an independent, sovereign, democratic, unitary, legal, secular and social government;

2) The Kyrgyz Republic (Kyrgyzstan) is an independent, sovereign, democratic, unitary, legal, secular and social government;

3) The sovereignty of the Kyrgyz Republic is not limited and extends to its entire territory; 
4) The Kyrgyz Republic independently conducts domestic and foreign policy;

5) The Kyrgyz Republic people are the bearers of sovereignty and the only source of government power;

6) The people of Kyrgyzstan are citizens of all ethnic groups of the Kyrgyz Republic;

7) The President and the Jogorku Kenesh have the right to speak on behalf of the people of the Kyrgyz Republic (Kyrgyz Republic Ministry of Justice, 2021).

\section{Research Methods and Materials}

In this article, the analytical work with various types of research methods were used (Ayupov, 2016: p. 15). In the process of analysis, general research methods were used, in particular, empirical research based on the description, comparison, observation.

Observation is used as fixing the properties and connections in analyzed objects, to obtain data on their shape, properties and relationships. The comparison method was chosen as a methodological basis for comparing objects to identify differential features.

The analysis structure contributes to consideration of questions about regularities of political systems functioning and is devoted to studying theoretical and methodological aspects affecting the government development concept, the formation of political and legal relations. The structure of political systems are considered in the example of the Central Asian governments, the place and role of the government in the regulation of political relations, as well as certain internal problems (Laumulin, 2016: p. 96).

The second part of the analysis is describing a study of political systems that reveal patterns of their functioning in general and in particular, in the conditions of the transition period. Among the aspects under consideration, the strategic goals of the Central Asian region, the stages of reforming political systems were classified, their transformation is theoretically comprehended, and the fundamental basis is revealed, as well as the Constitution primacy.

A generalized description and experience of governments in creating favorable social and legal conditions for the development of institutions of the political system presented. Much attention was paid to decentralization methods forms and the development of local self-government (LSG) institutions. Considerable attention is paid to the governments' integration issues within the Central Asian region and the problems of government security and participation in international institutions (Temirbekova, 2020).

\section{Results and Discussions}

Results basis in this work are consisting of political system development prerequisites in Central Asian Governments, political category transformation theories noted by several scientists, social modernization in CA countries and their political development models; economic transformation peculiarities with mar- 
ket economy reforms were described.

\subsection{Development Prerequisites of Political Systems in Central Asian Governments}

Let us consider the prerequisites for the development of political systems in the Central Asian governments, which can be conditionally divided into the following stages:

- System-wide prerequisites translated as the definition of legal, ideological and political conditions that characterize the basic society establishments and the type of government.

In turn, they are subdivided into foreign policy (sovereignty, stability of strategic priorities; multidimensionality of politics) and internal political (the formation of democracy; optimization of public administration structures);

- Systemic prerequisites translated as the sum of results in institutional and legal development, mechanisms of their interaction and institutions functioning;

- Intersystem prerequisites that ensure the effectiveness of the reform.

It is advisable to recognize that several features characterize political systems:

1) National independence through implementation as a subject of international relations;

2) The resource potential of the government is the material basis of sovereignty.

In the proposed circumstances, analysis and synthesis were also actively used, as a method based on the application of the sum of the laws of dividing objects into main parts (analysis) and combining several objects into a single whole (synthesis), which ensured high efficiency in their complex use.

It should be recognized that most problems require the use of special methods that are studied and improved in specific social sciences. At the same time, they are not arbitrary due to the characteristic properties of the investigated object.

It is also advisable to admit that in regional studies sociological methods are used as special methods. Then, under the political system, it is advisable to understand a complex system that encompasses the processes of development, formation and functioning of a set of socio-political institutions and sub institutions. At the same time, the practical tasks of the presented analysis are:

- Analysis of objects, subjects and processes taking place in society;

- Forecasting, in other words, foreseeing the development of the sum of sociopolitical processes;

- Development of decisions at the government level (Khamidova, 2013).

It should also be assumed that data cannot be used as a ready-made model of management decisions. They are mostly seen as a kind of "consultation".

In world practice, the transition from "socialist society" to capitalism has been studied sufficiently, but it is of great scientific and practical interest. Of course, the Central Asian governments, like many other CIS governments, were focused on the theory of political transformation and modernization, in general, explaining the sources, goals and direction of changes from totalitarianism to democra- 
cy. The international political discourse characterizing CIS governments as countries with authoritarian regimes offering no interest for scholarly analysis and experts noted that democracy has developed in these countries (Abramova \& Vilisov, 2020: p. 7). The case of Russia's foreign policy has been ambitious toward Central Asian republics in recent years, focusing on the creation of an organization with the participation of Belarus and Kazakhstan, Kyrgyzstan and Tajikistan (Ibrahim, 2015: p. 186). The Central Asian case study focused on implications about climate and socio-economic changes that would have influence Central Asia, and how these could affect China and Russia (Central Asian Case Study, 2021).

\subsection{Political Category Transformation Theories}

Thus, the theory of transformation does not use the categories "capitalism", "socialism", and the political system does not depend on the nature of the formation, but on the type of dominant traditional structures and the transition to rational structures.

In social science (anthropology), many theories have been put forward, including the theory of "transformation of capitalism", "institutionalism", "post-industrial society" through which new views on the essence of the social and political development of capitalism have been formed.

For example, Wilton Hamilton at the beginning of the twentieth century introduces the category of "institutionalism" into scientific circulation, and defined it as a mode of action in the habits of groups and customs of people. Institutions meant customs, trade unions, the state, etc. It can also be noted that T. Veblen, W.C. Mitchell, J.R. Commons, K. Wittfogel, G. Myrdal, J. Galbraith, R. Heilbroner adhered to similar views on the concept of institutions. It is correct to admit that the main idea of institutionalism corresponding to a given system of values, traditions and culture. Hence, resources are considered concerning the social role of knowledge.

If we touch upon the theory of post-industrial society, then it must be admitted to ensure the effective functioning of the political system, a clear execution of government functions is required. However, with the powerful development of the economy, the government cannot perform more and more functions.

At the current stage of the socio-humanitarian studies development, the interpretation of political transformation implies a transition from totalitarianism and authoritarianism to democracy. Political modernization is the modernization of all political institutions that must quickly adapt to new conditions, goals, and society must have political institutions capable of pursuing a policy of innovation and absorbing the political participation of the masses.

The well-known political scientist R. Dahl in the theory of political transformation gives preference to real political movements that provide the opportunity to realize their interests without any depending on their content or source of discrimination, polyarchy (Dahl, 2013: p. 231).

For example, S. Huntington identifies the types of transitions: the classical li- 
near model of democratization (British, Swedish); a cyclical model based on the experience of developing countries; the dialectical model, when authoritarian and democratic regimes can replace each other (Huntington, 2003: p. 39).

The most important political institution for the formation of "pre-democracy", a transformation of the political systems of society is the definition of "democratic" politics. For the post-Soviet republics, the transition from a totalitarian system to a democratic began in the mid of 1980s in the XX century. It is also true to admit that in the analyzed political systems there is an active process of changing political paradigms.

\section{Social Modernization in Central Asian Governments}

The first implementations of social modernization gave rise to many disputes regarding the prospects and models of development of the post-Soviet republics. In the conditions of a transitional society in Kyrgyzstan and Kazakhstan, as T. T. Mustafin notes, "politics should be responsible for creating a mechanism to ensure the balance of interests, the integrity of the social organism, implying the preservation of the government integrative functions, democratic mechanisms for the formation of power structures, legitimization and institutionalization of the opposition, the formation of a competitive party system" (Mustafin, 2017: p. 27). Modernization in Kyrgyzstan is ongoing on the transition from traditional society to a modern, suggesting overcoming paternalism (Duisheeva, 2014: p. 67).

In the process of analyzing political systems, it is advisable to define several levels that interact in a unified paradigm of political development. These are, for example, interactions in the CA region:

- Interstate level, i.e. the level of relations with the countries of the near and far abroad in general and the systems of governments united in regional communities;

- National level, the scale of the relationship between the institutions of the political system within the government as a whole.

It is also possible to admit that the opinion is correct that Central Asian governments followed the path of the "shock therapy" model, the most typical features of which are:

1) Destruction of the central planning system and market introduction;

2) Accelerating the transfer of government property into the hands of private individuals with sufficient capital;

3) Orientation towards the creation of a market model as an end in itself, for the realization of which society must inevitably pay a high economic and social price (Dauletova, 2019).

\subsection{The "Kazakh Model" of Political Development}

Let us detail these positions from the standpoint of constitutional legislation analysis on the example of several Central Asian governments. Thus, the "Ka- 
zakh model" of political development is defined in the Constitution of the Kazakhstan Republic in article 2 of the Basic Law, it is constituted that the Republic of Kazakhstan is a unitary government with a presidential form" (Kazakhstan Republic Constitution, 2019). In article 49 it is argued that the parliament of the Kazakhstan Republic is the highest representative body with legislative functions (Kazakhstan Republic Constitution, 2019). Another concept of the political system of Kazakhstan belongs to Schmitz, who calls it co-optation, where the ruling elite delegated to the opposition (Laumulin \& Malik, 2010: p. 95).

It can be argued that Kazakhstan has followed the path of power liberalization and decentralization. Based on analysis of the norms of the Kazakhstan Republic Constitution, it is important to recognize the rights and freedom of the widest range guaranteed. In foreign economic activity, the highest priority for Kazakhstan is cooperation with its close geopolitical neighbors Kyrgyzstan, Russia and China.

\subsection{The "Kyrgyz Model" of Political Development}

For example, the "Kyrgyz model" is defined in the Basic Law of the Kyrgyz Republic Constitution established in 1993. Article 1 of the Constitution states that "the Kyrgyz Republic (Kyrgyzstan) is a sovereign, unitary, democratic, legal, secular, social government” (Kyrgyz Republic Ministry of Justice, 2010). Political power in Kyrgyzstan is managed by the Jogorku Kenesh, the President, the Government, and other central authorities.

Article 70 states that the Jogorku Kenesh (parliament) is the highest representative body exercising legislative power and control functions within the limits of its powers (Asanbekova et al., 2021: p. 269). The executive power in the Kyrgyz Republic is represented by the Government, subordinate ministries, state committees, departments, other executive bodies and the local government administration.

The Kyrgyz researcher M.T. Artykbaev, that the "Kyrgyz model" focused on privatization, price liberalization, a multiparty system is actively being formed, the presence of a free press and other attributes of liberal democracy. As a result, a society has emerged, if not democratic by Western concepts, then more pluralistic, by most criteria, than in the past (Artykbaev, 2017: p. 127).

However, diametrically opposite views on the nature of the "Kyrgyz model" of development have also been formed. Thus, D. Dzhunushaliev and V. Ploskikh, believe that "it was during the millennia that the original mentality of the Kyrgyz was preserved, which could become the core of the social order, the revival of the spiritual values of the nation" (Ploskikh \& Dzhunushaliev, 2018: p. 17).

\subsection{The "Tajik Model" of Political Development}

Considering the "Tajik model", which is defined in the Constitution of the Republic of Tajikistan generated in 1994, article 1 states that Tajik Republic is a sovereign, democratic, secular and unitary government (Tajikistan Republic Min- 
istry of Justice, 2016). Article 12 indicates that the basis of Tajikistan economy formed by various forms of ownership Majlis Oli (parliament), according to Article 48 of the Tajik Republic Constitution, is the highest representative and legislative body. In article 64 the norms fixed about the President, head of the government and the executive branch. Local authorities, according to article 76 consist of representative bodies that act within the limits of their powers.

Tajik Republic President E. Rakhmon noted that "any other model of social order in Tajikistan leads to destabilization and civil war. The overwhelming majority of the people, whose will is enshrined in the new Constitution, do not want this" (Rakhmonov, 1998: p. 26). Regarding the integration of Tajikistan with other Central Asian governments and the world community, it adheres to the principle "to participate in the work of interstate bodies created within the framework of the CIS". "Integration processes should be expanded based on multi-vector agreements and contracts" (Rakhmonov, 1998: p. 27). It is also important to note that Tajikistan is striving for a market economy, the creation of new democratic institutions, but these actions are largely fragmented. On the example of Tajikistan, it can be quite clearly seen that despite the form mating neo-patrimonialism, democratic values and orientations of citizens to a large extent is protected (Olimova \& Olimov, 2014: p. 177).

\subsection{The "Turkmen Model" of Political Development}

The "Turkmen model" of development, which is defined in the Constitution, 1992, as well as with the amendments made on December 27, deserves due attention. 1995 In Article 1 emphasizes that Turkmenistan is a democratic, legal and secular government in which state government is carried out in the form of a presidential republic (Government Custom Service Turkmenistan, 2008).

According to article 46 the highest government power in Turkmenistan is executed by the President (Belashchenko et al., 2018: p. 772), the Majlis, the Supreme Court, the Supreme Economic Court, and the Cabinet of Ministers. The Khalk Maslahaty, according to the norms of article 48, includes President, deputies of the Majlis, Khalk Vakillari, elected by the people: Chairman of the Supreme Court, Chairman of the Supreme Economic Court, Prosecutor General, members of the Cabinet of Ministers.

For example, the essence of the content of the institutions in political system can be found in article 54, where the norm is fixed: the President is the head of government and executive power, the highest official, the guarantor of national independence, territorial integrity, compliance with the Constitution and international agreements (Government Custom Service Turkmenistan, 2008).

It is also important to note that the Turkmen model is being implemented against the background of economic reforms, agrarian reforms and small-scale privatization. The specificity of the "Turkmen model" is based on the fact, that private structures are created not so much by replacing the government, which is explained by the generally low level of economic development, but also by the 
lack of national personnel and the narrow specialization of the leading sectors in the economy: agriculture oriented towards cotton production, while the industry on oil and gas. It was also noted that experiments are unacceptable in these leading sectors and there are still no sufficient prerequisites for large-scale denationalization.

In this regard, a problem arises to find mechanisms to attract Turkmenistan to integration on the scale of the CIS. It is also noted that the possibilities of integration for Central Asian governments can be extremely important since integration is most acceptable for states with different approaches of national development models.

In Turkmenistan, according to several authors, there is practically no parliamentary opposition, and the presidential power itself determines the strategy for the development of society, controls the activities of the media, courts, social movements, which contributes to ensuring stability in the country. However, there are other views that the presidential power has an "over-concentrated" appearance and already has hypertrophied tendencies of authoritarianism.

\subsection{The "Uzbek Model" of Political Development}

Let us present an analysis of the "Uzbek model" in the Uzbek Republic Constitution (December 8, 1991), as amended on December 28, 1993, according to article 76 the highest government body is the Oliy Majlis (parliament), which exercises legislative power. In article 89 the legislator formalizes such a model where the President is the head of government and the executive branch. Also, the President is simultaneously the Chairman of the Ministers Cabinet (Uzbekistan Republic Constitution, 1992).

The analysis allows us to recognize that the newly independent governments in Central Asia currently have their models of development, strengthening sovereignty and building a democratic society, which creates favorable preconditions for deepening regional integration and expanding international cooperation.

\section{Political System and Economic Transformation Peculiarities in Central Asian Governments}

It is also advisable to note that the peculiarities of the political systems in Central Asian governments are including various political regimes, established after the Soviet Union collapsed (Kuzmina, 2009: p. 116). Thus, against the background of the authoritarian political regimes of the Central Asian governments, Turkmenistan stands out, where the political regime of the absolute power of the President operates. Authoritarian regimes have been established in Kazakhstan and Uzbekistan. However, Tajikistan is characterized by a model where the opposition entered into an alliance with the government and became a part of it, so as not to ignite a civil war.

At the same time, in the above governments, the standard of living has dropped specially and objectively and catastrophically, which is also an echo of the ongo- 
ing crisis collapse of the world economy in the context of post-pandemic development.

For Kyrgyzstan, the transition to democracy (Toktosunova, 2019: p. 26) has been marked by a series of popular protests. On March 24, 2005, the family and clan authorities of A. Akaev were overthrown. The new political power of K. Bakiev, starting in 2005, also continued the family-clan tradition of governance and was also overthrown on April 7, 2010.

Of course, the political systems of the Central Asian governments are fundamentally differentiated. However, among the common features, it is advisable to include the democratization and liberalization of social and political life, the actualization of political and economic reforms.

The liberalization led to economic transformations dictated by the search for a "new path". These are, for example, attempts to combine private entrepreneurial incentives with the preservation of the share of state property, which can be seen in the example of privatization of economic objects, its scale and nature, which manifested itself in the practice of various CA governments. It is logical to consider and differentiate the substantive essence of the terms "denationalization" and "privatization" in the laws and regulations of these governments.

For example, the term "denationalization" has identical content and implies "transformation of government-owned enterprises with the transfer of management functions directly to economic entities". In Uzbekistan, under denationalization, the national legislator translates the transformation of government-owned enterprises into collective, joint-stock and other companies and other structures that are not state-owned, meaning the alienation of property from the government, i.e. privatization.

In the legal sense, "privatization" for the above governments has a certain degree of unification and is translated as the acquisition of property objects or governments corporations, JSCs from the government.

It is appropriate to pay attention to some differentiation in the interpretation of the goals of privatization and the laws that ensure it. Thus, in Uzbekistan, privatization was carried out in the context of creating a socially oriented market economy; in the Republic of Kazakhstan to form various forms of ownership, form competition and entrepreneurship, and a socially oriented market economy; in the Kyrgyz Republic to create a market economy with a wide range of subjects of privatization and to remove from the government functions in managing enterprises.

\section{Market Economy Reforms in Central Asian Governments}

It is correct to admit that the structural restructuring of the economy in the Central Asian governments correlated with the specific socio-economic realities of each country and differs in pace: from radical market reforms in the Kyrgyz Republic, transformations by administrative and economic methods and strengthening government regulation of the economy in Uzbekistan and Turkmenis- 
tan, to market reforms under conditions political instability in Tajikistan.

Consequently, it is also advisable to recognize that the reforms were aimed at creating a model of a market economy (Spechler, 2005: p. 77), with a change in the paradigm of the form of ownership, participation of the government in ensuring the efficiency of the economy, regulating income and employment of the population, creating conditions for meeting the needs in education, health care, and culture.

Thus, the socially oriented market economy of the above-mentioned Central Asian governments is a way of harmoniously combining economic efficiency with social balance, requiring new conceptual views.

It is important to note that the ongoing reforms did not give effective results, and liberalization exacerbated the difficulties against the background of the required level of denationalization and privatization, the preservation of monopoly in the economy, the collapse of economic ties in the CIS, an attempt being made to modernize and revive the reforms.

Thus, in Uzbekistan, the principle of gradual implementation of reforms and their implementation in a controlled manner in the interests of the people, taking into account the readiness of society to perceive market relations, caused their delay and began in 1994.

In Turkmenistan, the reform process took place under the control of the government, and although the Constitution recognizes a plurality of forms of ownership, the government form prevails in the economy, especially in priority sectors of production that provide the bulk of the national income.

Under the conditions of the civil war in Tajikistan, the implementation of the economic revival has become very problematic and has led to complete dependence on international donors financing the declining, depressed economy of the country against the background of active migration of the working-age population out of the country. The serious consequences of the civil war at the turn of the century can be felt at the current stage in Tajikistan when most of the population lives below the extreme poverty line.

During the transitional period in Central Asia, political regimes were formed that occupy an intermediate position between totalitarianism and democracy, which are characterized as authoritarian.

It is also correct to note that the socio-political basis of the Central Asian states has a general tendency, the economy of which is based on the diversity of property, and the economic processes are focused on denationalization, privatization and the attractiveness of investment policy.

\section{Conclusion}

Summarizing results of above theoretical and legal analyses of essential content category "political system" in the Central Asian governments, it is possible to substantiate some conclusions:

1) The commonality of government and political conditions in Central Asia 
contributed to the formation of integration, expressed in an easier way of resolving interstate problems. The general prerequisites for gaining sovereignty and territorial integrity pose problems of an identical order to the Central Asian countries;

2) In the political system of the Central Asian governments as a whole, parliamentarian has been formed as a political and legal phenomenon that requires its further formation in the context of constitutional dynamism;

3) During the transition period in Central Asian governments, political regimes were formed that occupy an intermediate position between totalitarianism and democracy, which are characterized as authoritarian;

4) Constitutionalism, as an element of democratization in the Central Asian governments, is in the process of formation;

5) Reforms in the CA governments were aimed at creating a new economy with a change in the paradigm of the form of ownership, participation of the government in ensuring the regulation of income and employment of the population;

6) In Central Asia, there is a process of transformation of the bureaucratic model of the political elite into an oligarchic one, where the composition of the political elite becomes a symbiosis of the administrative and political nomenclature and leading political and financial groups using tribalism and the tribal factor, which affects the functioning of political institutions.

\section{Conflicts of Interest}

The authors declare no conflicts of interest regarding the publication of this paper.

\section{References}

Abramova, M., \& Vilisov, M. (2020). The Post-Soviet Transition: Constitutional Structuring and Political Reality (CIS Countries Case-Study). Cuestiones Constitucionales, No. 42, 3-38.

Amanbaev, B. A., \& Aitieva S. Z. (2009). To the Questions of Political Modernization and Transformation: Transition to Democracy. Science, New Technologies and Innovations of Kyrgyzstan, 1-2, 238-241.

Artykbaev, A., Amanbaev, B., \& Aitieva, S. Z. (2009). Models of Political Development of the Post-Soviet Republic. Science and New Technologies, 1-2, 137-139.

Artykbaev, M. T. (2017). Institutionalization of the Political Systems of the Post-Soviet Republics: Research Methodology (289 p).

Asanbekova, D., Osmonova, A., Abdyldaev, I., Begaliev, E., Ashimov, K., Nurmamat kyzy, K., Narbaev, O., Karimov, S., \& Abdullaeva, Z. (2021). Political System in the Sovereign Kyrgyzstan. Open Journal of Political Science, 11, 266-272. https://doi.org/10.4236/ojps.2021.112018

Ayupov, A. N. (2016). National Economy (2nd ed., pp. 13-15). Kyrgyz Russian Slavic University.

Belashchenko, D. A., Ryzhov, I. V., \& Shodzhonov, I. F. (2018). Formation of the Political Elite of Turkmenistan and Its Influence on the Process of Making. Political Science, 45, 
766-774. https://doi.org/10.18413/2075-4458-2018-45-4-766-774

Central Asian Case Study (2021). Impacts and Risks from High-End Scenarios: Strategies for Innovative Solutions. IMPRESSIONS Information Hub.

http://www.highendsolutions.eu/page/central asia

Central Commission for Elections and Referendums (2021). Elective Right. URL https://shailoo.gov.kg/ru/izbirateli-shailoochular/izbiratelnoe pravo shailoo ukugu/

Dahl, R. (2013). Modern Political Analysis (2nd ed., 231 p). Political Science.

Dauletova, Z. M. (2019). Camparativistic Analysis of the Political Systems of Kyrgyzstan and Kazakhstan. International Journal of Humanities and Natural Sciences, 9-1, 46-49.

Duisheeva, R. (2014). Preconditions and Factors of Transformation of the Political System of Kyrgyzstan. Central Asia and the Caucasus, 17, 62-75.

Elebaeva, A., \& Pukhova, M. (2007). Transit in the Context of the Political Development of Modern Kyrgyzstan (1991-2006). Central Asia and the Caucasus, 2, 79-91.

Huntington, S. (2003). The Third Wave: Democracy at the End of the Century(286 p). University of Oklahoma Press.

Ibrahim, M. (2015). The Political Role of Russia: A Case Study of Central Asian Muslim States. Journal of Public Administration and Governance, 5, 182-189. https://doi.org/10.5296/jpag.v5i1.7389

Kazakhstan Republic Constitution (2019). Kazakhstan Republic Constitution. URL. https://online.zakon.kz/document/?doc id=1005029

Khamidova, Z. (2013). Transformation and Modernization Processes in the Post-Totalitarian Political Systems. Science and New Technologies, 6, 170-172.

Kuzmina, E. M. (2009). Features of the Internal Political and International Situation in Central Asia and Their Impact on Integration Processes. Political Expertise: Politex, 5, 116-133.

Kyrgyz Republic Ministry of Justice (2010). Kyrgyz Republic Constitution. URL. http://cbd.minjust.gov.kg/act/view/ru-ru/202913

Kyrgyz Republic Ministry of Justice (2021). Kyrgyz Republic Constitution. URL. https://www.gov.kg/ru/p/constitution

Laumulin, M., \& Malik, A. (2010). Central Asia: Basic Approaches in Contemporary Political Science. Central Asia and the Caucasus, 13, 90-109.

Laumulin, M. T. (2016). On the Question of the Formation of Post-Soviet Statehood in Central (Central) Asia. The Contours of Global Transformations: Politics, Economics, Law, 9, 95-113. https://doi.org/10.23932/2542-0240-2016-9-5-95-113

Malysheva, D. B. (2018) Political Processes in the Post-Soviet Central Asia. Contours of Global Transformations: Politics, Economics, Right, 11, 36-52. https://doi.org/10.23932/2542-0240-2018-11-3-36-52

Melnikov, M. V. (2018). Peculiarities in Formation of the Political System of the Republic of Turkmenistan. Modern Science and Innovations, 1, 190-193.

Mustafin, T. T. (2017). Methodical and Scientific Problems of Political Science (2nd ed.). Almaty.

Olimova, S., \& Olimov, M. (2014). Public Opinion, Democracy and Authoritarianism in Central Asia. Central Asia and the Caucasus, 17, 158-178.

Ploskikh, V. M., \& Dzhunushaliev, D. D. (2018). Kyrgyz and Kyrgyzstan History (2nd ed., $365 \mathrm{p})$.

Rakhmonov, E. (1998). Long Way to Peace (100 p). Sharki Ozod. 
Shukuralieva, N. (2007). Problems of Constitutionalism in the Republic of Kyrgyzstan. Central Asia and the Caucasus, 6, 7-18.

Spechler, M. (2005). Central Asia: Between West and East. Central Asia and the Caucasus, 5, 74-89.

Sydykov, B. S. (2014). Interaction of National, Regional and Global Models of International Cooperation in Central Asia (327 p).

Tajikistan Republic Ministry of Justice (2016). Tajikistan Republic Constitution. URL. https://adliya.tj/ru/constitution

Temirbekova, A. T. (2020). Change of the Political System of the Kyrgyzstan Society in the Side of Parliamentary Republic Formation. Bulletin of the Kyrgyz State Technical University. I. Razzakov, 3, 455-460.

Toktosunova, A. I. (2019). Parliamentary Democracy in Kyrgyzstan: Utopia or Reality? Historical and Socio-Educational Thought, 11, 24-45.

https://doi.org/10.17748/2075-9908-2019-11-4-24-45

Government Custom Service Turkmenistan (2008). Turkmen Republic Constitution. URL. https://www.customs.gov.tm/ru/laws/konstitutsiya-turkmenistana

Uzbekistan Republic Constitution (1992). About Constitution. URL.

http://constitution.uz/ru 